\title{
A Review of Chemical Engineering on Handling Environmental Challenges
}

\author{
Greeshma Gopisetti* \\ Department of Biotechnology,Jawaharlal Nehru Technological University Hyderabad, Hyderabad, India
}

\begin{abstract}
Chemical Engineering is becoming to be a most used methods in achieving the solution for problems being faced in environmental challenges. Environmental issues like waste water treatment, waste management, pollutants for air, water and soil remediation, etc can be treated with chemical engineering techniques like physicochemical processes, advanced oxidation processes, biological processes, and many other sustainable technologies. The article provides a review on solutions provided by chemical engineering for few environmental problems.
\end{abstract}

Keywords: Chemical engineering (ChE), Environmental issues, waste treatment, water disinfection

\section{Introduction}

Environmental challenges are very complex and Chemical Engineering (ChE) is tending to be to be an imported method to provide solutions for wide range of environmental problems [1]. Methods of ChE like designs of chemical reactors, modelling, simulation, kinetics, control, modelling and heat and mass balances can be extensively used tending the challenges we are facing in current world.

Environmental problems like removal of hazardous wastes, reactions of toxic substances, synthesis and design of non-polluting plants, global air pollution, and water chemistry. Most environmental problems are highly complex and often are not clearly demonstrated [2]. Chemical engineering disciplines have been immensely used for clearing the challenges of environment like treatment of waste water, bio-filtration, anaerobic digestion, biodegradable plastics, etc [1].

Through these CE fundamentals, a lot of environmental processes have been described and designed. However, environmental science and technology is evolving so fast that some processes still need a CE approach.

Main and foremost issue that can be resolved using chemical engineering is the management of waste. The oceans are filled with the waste of plastic, biological, electronics, and lots and lots of junk that has been discarded either by the human usage in homes, offices, industries, and many others. Another issue that can be resolved is treatment of water. Removing contaminants from the water is a crucial yet important method for industrial processes. The water treatment processes is to reduce the relevant contaminants in the water so it can be used for relevant use. Other environmental issues are addressed by $\mathrm{ChE}$ are decomposition of pollutants for air, water and soil remediation, hydrogen production, $\mathrm{CO} 2$ reduction and biomass valorization and many others.

Treatment of biological waste is one of the methods that can be approached by chemical engineering and current research suggests ChE approaches are turning to be a solution for this issue. The previous methods of regular composting that is a well used technology, this method has is a rigid process that lacks new possibilities. However, application of the ChE to this issue has now transformed it as a new paradigm of circular economy to convert wastes into new bioproducts, which are only primary approaches to use the CE paradigms [1]. Some studies on composting modelling, or even the use of Computational Fluid Dynamics (CFD) can be useful and solid-state experiments can be realistic and reliable while using some grams of substrate in sterilized and controlled lab conditions [1,3]. Chemical engineers are making new designs and techniques regularly to improve more sustainable methods for waste management.

Photocatalysis can conveniently replace the regular wastewater treatment technology, due to its utilization of visible light to photo-degrade organic and inorganic contaminants [4]. There has been a tremendous improvement in this method in last 20 years. Major application of solar

*Correspondence to: Greeshma Gopisetti, Department of Biotechnology, Jawaharlal Nehru Technological University Hyderabad, India, E-mail: gn_greeshma@ yahoo.com

Citation: Gopisetti G (2020) A Review of Chemical Engineering on Handling Environmental Challenges. J Catal Chem Eng Adv 7(1): 103. DOI: https://doi. org/10.47275/2693-7182-103.

Received: June 10, 2020; Accepted: July 23, 2020; Published: July 24, 2020

Copyright: (C) 2020 Gopisetti G. This is an Open Access article distributed under the terms of the Creative Commons Attribution 4.0 International License (CCBY) (http://creativecommons.org/licenses/by/4.0/) which permits commercial use, including reproduction, adaptation, and distribution of the article provided the original author and source are credited. 
photocatalytic treatment water is degradation of organic pollutants present in air, water streams which is considered as advanced oxidation processes [5]. Sunlight is used for of water disinfection and heliophotocatalysis by titanium dioxide $\left(\mathrm{TiO}_{2}\right)$ can be considered as a new approach to water disinfection [6].

Adsorption process can be answer for the challenges related to the need of clean air, water and soils and relevant topics as the processing of diluted aqueous solutions and valorization of biomass [7]. Another major challenge that is wide spread in the universe are global warming from greenhouse gases. Another issue is surrounding large-scale carbon capture and storage (CCS) to prevent the release of carbon dioxide $\left(\mathrm{CO}_{2}\right)$ into the atmosphere. Adsorption processing can be the solution for these pollution and green house gases issues.

Rodrigues gave a final word in one of this article that "Chemical Engineers combine expertise in chemistry, physics, mathematics and some in biology with an engineering thinking and are players in many frontier areas to develop Sustainable processes/products and help solving Environmental challenges" [7].

\section{References}

1. Sánchez A. 2019. The current role of chemical engineering in solving environmental problems. Front Chem Eng 1: 1.https://doi.org/10.3389/fceng.2019.00001

2. Seinfeld JH. 1991. Environmental Chemical Engineering. Advances in Chemical Engineering 16: 267-292.https://doi.org/10.1016/S0065-2377(08)60157-X

3. El-Bakry M, Abraham J, Cerda A, Barrena R, Ponsá S, et al. 2015. From wastes to high value added products: novel aspects of SSF in the production of enzymes. Crit Rev Environ Sci Technol 45: 1999-2042.https://doi.org/10.1080/10643389.2015.1010423

4. Yahya N, Aziz F, Jamaludin NA, Mutalib MA, Ismail AF, et al. 2018. A review of integrated photocatalyst adsorbents for wastewater treatment. J Environ Chem Eng 6(6): 7411-7425. https://doi.org/10.1016/j.jece.2018.06.051

5. Bahnemann D. 2004. Photocatalytic water treatment: solar energy applications. Solar Energy 77(5): 445-459.https://doi.org/10.1016/j.solener.2004.03.031

6. Rincón AG, Pulgarin C. 2007. Solar photolytic and photocatalytic disinfection of water at laboratory and field scale. Effect of the chemical composition of water and study of the postirradiation events. J Sol Energy Eng 129(1): 100-110.https://doi.org/10.1115/1.2391308

7. Rodrigues AE. 2020. Chemical engineering and environmental challenges. Cyclic adsorption/reaction technologies: materials and process together. J Environ Chem Eng 8(4): 103926. https://doi.org/10.1016/j.jece.2020.103926 